\title{
Study on Control of Fatigue Crack Propagation by Pulsed Laser Irradiation
}

by

\author{
Kenji $\mathrm{I}_{\mathrm{NADA}}{ }^{*}$, Masayuki $\mathrm{A}_{\mathrm{RA}}{ }^{* *}$, Kiyohiro $\mathrm{I}_{\mathrm{TO}}{ }^{* *}$, Hiroki $\mathrm{Y}_{\text {OKOTA }}{ }^{* * *}$ and Tatsuo $\mathrm{S}_{\mathrm{UIDZU}}$ ***
}

It is required to establish a technique for repairing a cracked structural component as well as for evaluating precisely crack initiation life in a main component of land-based gas turbine. It is known that the weld overlay technique is one of repairing processes and is widely applied to aged components in thermal power plants. However, the aged combustor in gas turbine has been replaced with a new one. Expensive alloys such as cobalt based and nickel-based super alloys have been used, which lead to increase of maintenance cost. This gave us motivation to develop an alternative repairing process, fiber laser process, to repair a fatigue crack initiated at the edge of stress concentrated part in thin-walled structures. In this study, residual stress is induced by irradiating a laser ahead of fatigue crack tip, and the delaying effect of residual stress on crack propagation rate is then evaluated. SUS 304 plate specimen with a hole was prepared and fatigue loading was enforced to induce natural cracks at the edge of the hole. Then, the area ahead of crack tip was irradiated by fiber laser and fatigue crack propagation behavior was examined. It was clarified that fatigue crack propagation rate was delayed to approach the laser irradiated area. It was confirmed that tensile residual stress was formed in the laser irradiated area by a hole drilling method. As a result, it was proven that fiber laser can be used as the advanced repairing process to repair a fatigue crack.

Key words:

Fatigue Crack Propagation, Delaying Effect, Single-Pulse Laser Treatment

\section{1 緒言}

高度経済成長期に建設・製造された発電設備, 化学プラ ント, 橋梁, ビル, 道路などのインフラ設備においては, 設計寿命を大幅に超えた所謂経年劣化した状態に達して いる.とりわけ火力発電設備では, 地方自治体からの環境 影響評価に基づいた設置認可が困難な状況にあり，新設 設備の建設は難しい.このため, 経年劣化した設備の健全 性を保証しつつ長期にわたりこれらを使用し続けること, ガスタービンとの組み合わせによる高効率化を図ること が積極的に進められている. 前者においては, タービン, 過熱器/再熱器チューブ, 配管溶接部での疲労, クリープ き裂の発生とその進展を適切に評価することが求められ る ${ }^{1)}$. 後者においては, メタル温度が $1000^{\circ} \mathrm{C}$ を超えるた め, 燃焼器, 動翼などの主要高温機器は冷却孔を有した薄 肉構造体となっている。このため, 円孔縁から発生した熱 疲労き裂を適切に評価しなければならない2).

ところで, 経年劣化したこれらの設備に生じたき裂発 生と進展を適切に評価する技術とともに，き裂を有する 部材を補修する技術を確立することもまた重要である ${ }^{3)}$.

\begin{abstract}
火力発電設備に対する代表的な補修技術として肉盛溶接

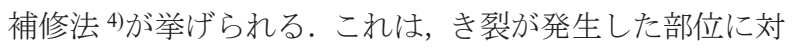
して肉盛溶接することで補修する方法である. 多くの場 合，き裂を覆うようにして補修が行われる，一方，ガスタ ービンの主要高温機器においては, き裂が発生した部品 に対しては新品に置き換えられている．主要部品ではコ バルト基超合金あるいはニッケル基超合金といった高価 な材料が使用されている.このためにメンテナンスコス トの増加が問題となっている5).

このような背景に鑑みて, 著者らは薄肉構造体におけ る応力集中部から発生した疲労き裂を補修するための技 術開発を進めている. そのうちのひとつとして, 近年関心 が集まっているファイバーレーザの適用の可能性につい て検討している ${ }^{6), 7)}$. ファイバーレーザは, 単一モード光 ファイバーとして希土類元素を添加したレーザ媒体を適 用し，その媒体の外側にはクラッド層を設ける。これによ り，これまでにない高密度なレーザ出力を達成できると ともに, 連続光, パルス光にも設定できる点に特徵がある. さらには, レーザ発信器がコンパクトであることから, 現
\end{abstract}

$\dagger$ 原稿受理 令和元年12月9日 Received Dec. 9, 2019 (2020 The Society of Materials Science, Japan

* 学生会員 東京理科大学大学院 工学研究科機械工学専攻 ₹125-0051 東京都葛飾区新宿

Department of Mechanical Engineering, Tokyo University of Science, Katsushika-ku Tokyo 125-8585

** 正会員 東京理科大学大学院 工学研究科機械工学専攻 ₹125-0051 東京都葛飾区新宿

Department of Mechanical Engineering, Tokyo University of Science, Katsushika-ku Tokyo 125-8585

*** トーカ口(株) 溶射技術開発研究所 $=674-0093$ 明石市二見町南二見

TOCALO Co.,Ltd., Futamichominami, Akashi, 674-0093 
場で容易にレーザ光を利用できる。このような利点を踏 まえて, 疲労き裂を直接レーザ照射することでき裂面を 溶融し, 元の形状に回復することを試みてきた。この結果, 比較的長いき裂に対してレーザ照射することで補修され た材料のき裂発生寿命は，無補修材のそれと同程度まで 回復することを報告している ${ }^{8}$. ただし，レーザ照射条件 によっては照射領域が脆化することで疲労き裂進展速度 が加速する場合もあることがわかった。

ところで Arai は圧入された介在物周辺に発生した残留 応力がその近傍を進展するき裂進展経路に及ぼす影響を 解析的に予測している ${ }^{9}$. その結果, 圧縮残留応力場がき 裂進展経路に強く影響を及ぼすことを明らかにしている。 そこで本研究では, 疲労き裂先端近傍にレーザをスポッ 卜照射することで残留応力を付与し，疲労き裂進展を抑 制することを試みる。ガスタービン燃焼器においては多 数の冷却孔を有した薄肉構造体であり，これら冷却孔縁 から疲労き裂が発生することが報告されている ${ }^{10)}$ 。この ような疲労き裂に対して次回定期検査まで本手法により 簡便に補修できれば，メンテナンスコストの著しい低減 が期待できる. 本報では，モデル材料としてステンレス鋼 SUS304 を対象に，円孔縁に存在する疲労き裂先端近傍に 対してレーザをスポット照射し，有限要素解析を通じて スポット照射位置による疲労き裂進展の遅延効果を検討 する.さらに, 疲労き裂進展試験によりその有効性を実証 する.

\section{2 有限要素解析}

\section{$2 \cdot 1$ レーザ照射により生じる残留応力のモデル化}

耐熱材料表面をパルスレーザにより半径 $a$ の領域を照 射し, 溶融させたときに生じる残留応力について考える. ところで，Mukherjee らは 3D レーザ積層造形体に生じる 残留応力とゆがみを推定している ${ }^{11)}$ 。そこでは，熱伝導 解析と熱弾塑性解析を連成させることでレーザ照射領域 近傍に生じる残留応力を評価した。これに対して本研究 では円孔に介在物を圧入する方法により残留応力を評価 することとした．評価手順について以下に説明する。
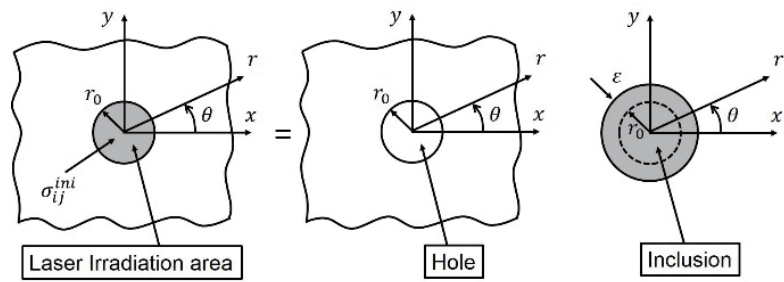

Fig. 1 Inclusion model for simulating residual stress generated due to laser irradiation.

Fig. 1 に介在物圧入による残留応力評価手順を模式的に 示す. 図に示す様に, 無限平板中に半径 $r_{0}$ の円孔が存在す るものとする。この円孔に対して材質が等しい半径 $r_{0}+\varepsilon$ の円形介在物を挿入することで，パルスレーザ照射によ り生じた残留応力を表現する。ここで，パラメータとはレ
ーザ溶融したことで材料に生じた相変態や溶融収縮量を 表す。本解析では本パラメータが疲労き裂進展経路にど のような影響を及ぼすのか調べることとした。

無限弾性平板中に存在する半径 $r_{0}$ の円孔へ半径 $r_{0}+\varepsilon$ の 円形介在物を挿入することで介在物中 $\left(0 \leq r \leq r_{0}\right)$ に生じ る平面応力状態での応力成分は,

$$
\left\{\begin{array}{c}
\sigma_{r r}=\sigma_{\theta \theta}=-\frac{E}{2}\left(\frac{\varepsilon}{r_{0}}\right) \\
\sigma_{r \theta}=0
\end{array}\right.
$$

となる.ここで, $E$ は対象材料の縦弾性係数である.また, その外側 $\left(r_{0} \leq r<\infty\right)$ では,

$$
\left\{\begin{aligned}
\sigma_{r r}=-\sigma_{\theta \theta} & =-\frac{E}{2}\left(\frac{\varepsilon r_{0}}{r^{2}}\right) \\
\sigma_{r \theta} & =0
\end{aligned}\right.
$$

のように残留応力が分布する.

一方, 円孔への介在物の圧入問題を有限要素解析では 扱うことができない，そこで本研究では，有限要素解析モ デルを，1)円孔を有する弾性平板と 2) 初期応力 $\sigma_{i i}^{i n i}(i=$ $r, \theta)$ を有する円孔の半径に等しい弾性円板からなるもの とする. そして, 初期応力を有する弾性円板と円孔の境界 面を連結し, 系全体が力学的平衡状態となるような解を 求めることとした. 後述する解析条件における縦弾性係 数に基づき得られた弾性円板中での応力成分は,

$$
\left\{\begin{array}{c}
\sigma_{r r} \\
\sigma_{\theta \theta}
\end{array}\right\}=g\left\{\begin{array}{c}
\sigma_{r r}^{i n i} \\
\sigma_{\theta \theta}^{i n i}
\end{array}\right\}
$$

のように関係づけられることがわかった。ここで，係数 $g=0.3503$ であった. なお, この係数は縦弾性係数により 異なった值をとることに注意を要する.よって, 式(1)と式 (3)により, パラメータ $\varepsilon$ と初期応力 $\sigma^{i n i}\left(\sigma_{r r}^{i n i}=\sigma_{\theta \theta}^{i n i}\right)$ の関 係は，

$$
\sigma^{i n i}=-\frac{E}{2}\left(\frac{\varepsilon}{g r_{0}}\right)
$$

で与えられる.この関係式に従い, 有限要素解析モデルに おけるレーザ照射領域に初期応力を与えることとした.

\section{$2 \cdot 2$ 解析モデルと解析方法}

有限要素解析により，レーザ照射位置およびレーザ照 射により生じた残留応力の大きさ (パラメータ が疲労き裂進展挙動に及ぼす影響について調べた。

本解析に用いた解析モデルの形状, その中心部の拡大 図, 境界条件を Fig. 2 に示寸. 有限要素解析には汎用有限 要素解析コード Marc2010（MSC Software Corporation 製） を用いた。本解析では形状の対称性を考慮して右側領域 のみを解析対象とした. 解析モデルは側面に半径 $15 \mathrm{~mm}$ の円弧状切欠きを有する厚さ $1 \mathrm{~mm}$ の平板形状であり，そ の中央部に半径 $1.5 \mathrm{~mm}$ の円孔が存在している.さらにこ の円孔に縁に長さ $1.5 \mathrm{~mm}$ の円弧状溝を，その先端に長さ $1 \mathrm{~mm}$ の初期き裂を設けた。これらは後述する疲労試験片 の形状に一致するよう配慮した. また, 解析モデル左端か らき裂先端までの水平距離をき裂長さ $a$ とした。初期き 
裂先端を原点に，き裂面に平行な方向に $r$ 軸，この軸を反 時計周りに角度 $\theta$ の極座標系をおいた。これにより, レー ザ照射位置，すなわち円孔に挿入された弾性円板の位置 を表すこととした．本解析で設定したレーザ照射位置 $r$ と その角度 $\theta$ の組み合わせを Table 1 に示す。なお，レーザ 照射半径 (円孔半径) を $r_{0}=0.5 \mathrm{~mm}$ とした. Table 2 に本 解析で設定したパラメータ $\varepsilon$ とそれに対応する弾性円板 に与えた初期応力 $\sigma^{i n i}$ をまめて示す. Fig. 3 に，一例と して, $r=2 \mathrm{~mm}, \theta=0^{\circ}$ のきの有限要素解析モデルに対 して要素分割したものを示す.

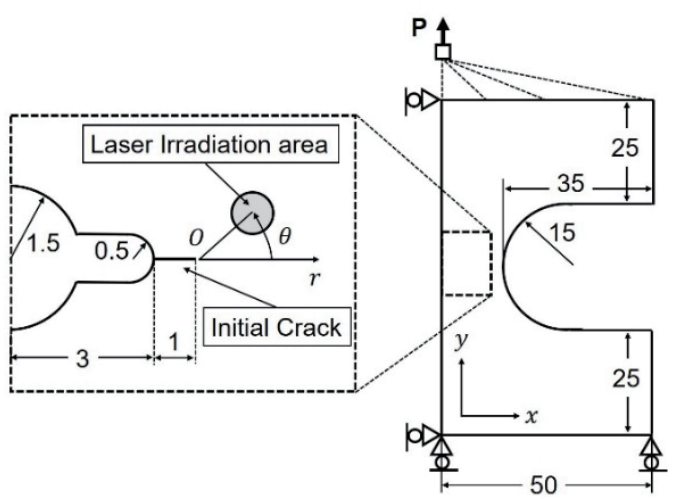

Fig. 2 FEM model prepared in this study (Dimensions in mm, plate thickness is $1 \mathrm{~mm}$ ).
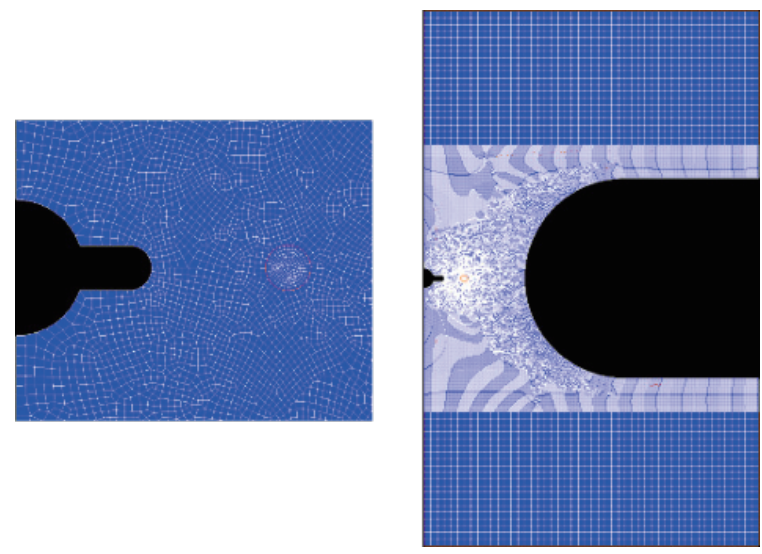

Fig. 3 FE model divided by mesh (Case of $r=2 \mathrm{~mm}$ and $\theta=0^{\circ}$ ).

Table 1 Analysis variables.

\begin{tabular}{|c|c|}
\hline$r[\mathrm{~mm}]$ & $\theta\left[^{\circ}\right]$ \\
\hline $2,3,4$ & $0,10,20$ \\
\hline
\end{tabular}

Table 2 Parameter $\varepsilon$ and related initial stress.

\begin{tabular}{|c|c|}
\hline$\varepsilon[\mathrm{mm}]$ & Initial stress $\sigma^{\text {ini }}[\mathrm{MPa}]$ \\
\hline 0.003 & -1695 \\
\hline 0 & 0 \\
\hline-0.003 & 1695 \\
\hline
\end{tabular}

解析モデルに使用した要素は 4 節点平面応力要素(Marc の要素タイプ 3)であり, 総要素数 14020 , 総節点数 14386
であった。また，ヤング率を $198 \mathrm{GPa}$ ，ポアソン比を 0.3 の弾性体と仮定し, フックの法則に従うものとした. また, き裂面に接触条件を与えることでき裂閉時にき裂面同士 が重ならないようにした。

解析モデルに対する境界条件として，モデル下端面の $y$ 方向変位を固定し，左端面の $x$ 方向変位を固定した。ま た，TYING 機能を用いてモデル上端面に設けた代表節点 に上端面に付属するすべての節点を拘束し，代表節点に 繰返し荷重を作用させた. 繰返し荷重条件は, 最大引張荷 重 $3300 \mathrm{~N}$, 最小荷重 $0 \mathrm{~N}$, 周波数 $3 \mathrm{~Hz}$ の三角波である.

応力拡大係数は Marc $の$ VCCT 機能を用いて算出し, き 裂進展方法にはリメッシュ法を用いた. なお, 疲労き裂進 展に必要なパリス則の材料定数については $C=2.24 \times 10^{-14}$, $m=3.07$ とした ${ }^{12)}$.

き裂進展解析において，任意の繰返し数に対するき裂 進展速度 $d a / d N$ を以下のように算出した. き裂進展解析 での繰返し数 $N$ を横軸に, き裂長さ $a$ を縦軸にプロットす る.そして，あるプロット点と一つ隣のプロット点に対し て区分線形補間を行う。これにより得られた直線の傾き からき裂進展速度 $d a / d N$ を算出した。

\section{$2 \cdot 3$ 解析結果ならびに考察}

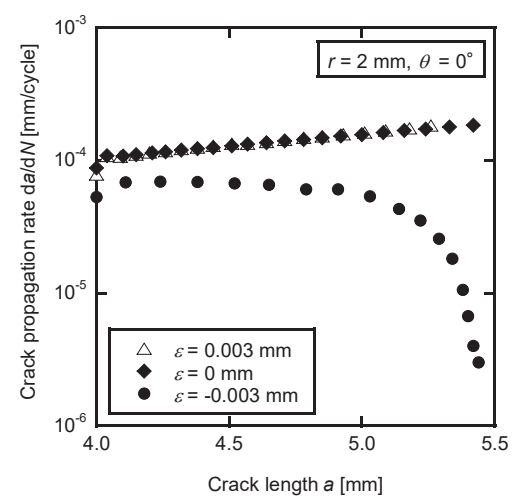

Fig. 4 Relationship between crack length $a$ and fatigue crack propagation rate $d a / d N$ (Case of $r=2 \mathrm{~mm}$ and $\theta=0^{\circ}$ ).

はじめに, 円孔の半径と弾性円板の半径の違い, すなわ

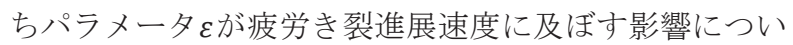
て検討した， $r=2 \mathrm{~mm}, \theta=0$ とししときに得られたき裂 長さ $a$ とき裂進展速度 $d a / d N$ の関係を Fig. 4 に示す. 図よ り, $\varepsilon=0 \mathrm{~mm}$ および $0.003 \mathrm{~mm}$ において, き裂長さの増加 に伴い疲労き裂進展速度は線形的に増加しており, 両者 の值はほとんど一致している. 一方, $\varepsilon=-0.003 \mathrm{~mm}$ のと き, 疲労き裂先端が弾性円板, すなわちレーザ照射領域に 近づくにつれて疲労き裂進展速度が低下していることが わかる．この理由を考察するため，弾性円板周辺のy方向 応力成分 $\sigma_{y y}$ について評価した. Fig. 5 に最大引張負荷時 の $\sigma_{y y}$ のコンター図を示す. 図より, $\varepsilon=0.003 \mathrm{~mm}$ のとき 弾性円板とき裂先端の間では高い引張応力が生じている. これに対して, $\varepsilon=-0.003 \mathrm{~mm}$ では, 同領域での応力場が 緩和していることがわかる. よって, 円孔の半径よりわず 
かに小さい半径の弾性円板を挿入することで圧縮残留応 力が生じてき裂前縁での応力場が緩和され，この応力場 が疲労き裂進展を遅延させることがわかった。

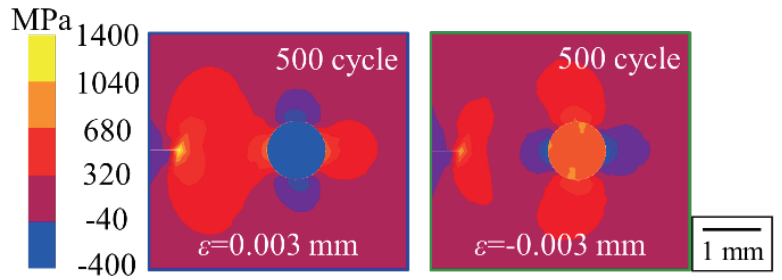

Fig. 5 Stress distribution of $\sigma_{y y}$ in the vicinity of the pressfitted elastic inclusion at maximum loading.

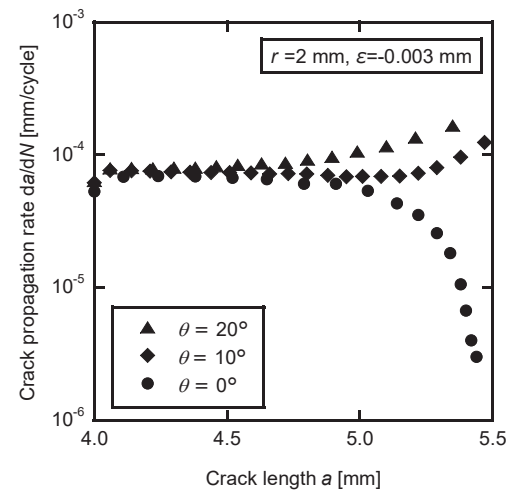

Fig. 6 Relationship between crack length $a$ and fatigue crack propagation rate $d a / d N$ (Case of $r=2 \mathrm{~mm}$ and $\varepsilon=-0.003$ ).

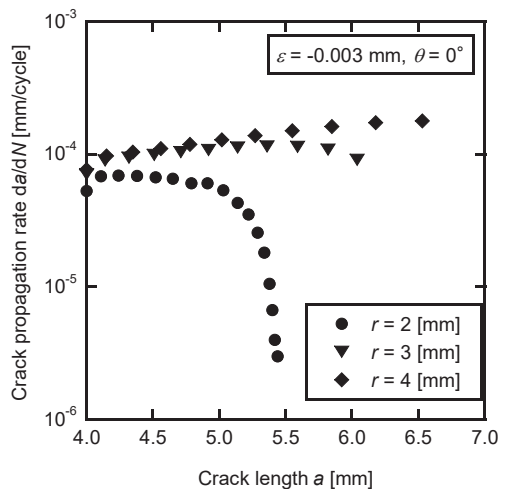

Fig. 7 Relationship between crack length $a$ and fatigue crack propagation rate $d a / d N$ (Case of $\theta=0^{\circ} \mathrm{mm}$ and $\varepsilon=$ $0.003)$.

つぎに, パラメータ $\varepsilon=-0.003 \mathrm{~mm}, r=2 \mathrm{~mm}$ として角 度 $\theta$ が疲労き裂進展速度に及ぼす影響について検討した。 Fig. 6 にき裂長さ $a$ とき裂進展速度 $d a / d N$ の関係を示す. 図より, 疲労き裂進展速度の著しい遅延が認められた $\theta=$ $0^{\circ}$ の結果に対して, $\theta=10^{\circ}, 20^{\circ}$ では, 疲労き裂先端が弾性 円板に近づくにつれて疲労き裂進展速度がやや増加して いる.

最後に, $\varepsilon=-0.003 \mathrm{~mm}, \theta=0$ ○として半径 $r$ 疲労き裂 進展速度に及ぼす影響について検討した．Fig. 7 にき裂長

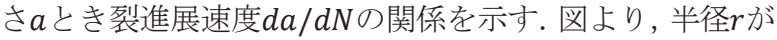
小さい, すなわちレーザ照射領域がき裂先端に近づくほ
ど疲労き裂進展速度が低下していることがわかる。以上 の有限要素解析結果を通じて, パラメータ わちレーザ照射領域が引張応力となるような残留応力と すること，レーザ照射位置を補修対象とするき裂先端の 前面近傍と寸ることが望ましいことがわかった。

\section{3 疲労試験}

本章では，予き裂の延長線上にレーザ照射した薄肉平 板形状の疲労試験片を対象に疲労試験を行うことで，パ ルスレーザ照射による疲労き裂進展の抑制効果を検討 する。

\section{$3 \cdot 1$ ファイパーレーザシステム}

本研究では $\mathrm{CW}$ 発振ファイバーレーザ(最大出力 2500 W）を使用した。本研究で用いたシステムは, CW 発振 のファイバーレーザ発振器を外部 I/O により ON/OFF 制 御するよう構成されており，パルス幅，繰返し周波数等 のパルス特性を制御できるよう工夫している。

\section{$3 \cdot 2$ 供試材と試験片形状}

供試材には冷間圧延加工された厚さ $1 \mathrm{~mm}$ のオーステ ナイト系ステンレス鋼 SUS304H 平板を用いた. Table 3 に SUS304H の化学組成を示寸. Table 4 に, 同ステンレ ス鋼のヤング率と $0.2 \%$ 耐力を示す.なお，これらの機械 的特性は，同平板素材から切り出された試験片を対象に 別途実施した引張試験により得た。この結果から，冷間 圧延材のため, 通常の焼きなまし材に比べ $0.2 \%$ 耐力が高 い.

Fig. 8 に疲労試験片形状を示す. 平板素材から図に示 す形状に機械加工したものを用いた.

Table 3 Chemical composition of SUS304H (wt $\%$ ).

\begin{tabular}{|c|c|c|c|c|c|c|c|c|}
\hline Element & $\mathrm{C}$ & $\mathrm{Si}$ & $\mathrm{Mn}$ & $\mathrm{P}$ & $\mathrm{S}$ & $\mathrm{Ni}$ & $\mathrm{Cr}$ & $\mathrm{Fe}$ \\
\hline $\begin{array}{c}\text { Chemical } \\
\text { composition }\end{array}$ & 0.07 & 0.47 & 0.97 & 0.032 & 0.004 & 8.06 & 18.22 & $\mathrm{Bal}$. \\
\hline
\end{tabular}

Table 4 Mechanical properties of SUS304H.

\begin{tabular}{|c|c|}
\hline Young's modulus [GPa] & $0.2 \%$ proof stress [MPa] \\
\hline 198 & 940 \\
\hline
\end{tabular}

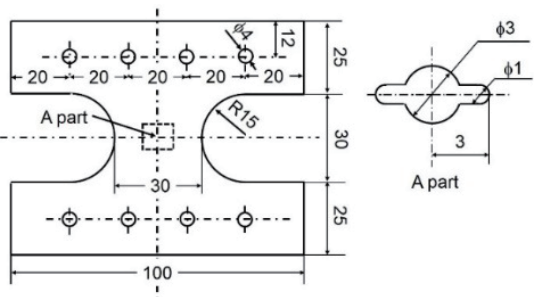

Fig. 8 Geometry of specimen for fatigue test (dimensions in $\mathrm{mm})$.

\section{$3 \cdot 3$ 試験方法}

疲労試験にはサーボパルサーEHF-EB50KN-20L (島津 製作所製, 最大負荷容量 $50 \mathrm{kN}$, 最大ストローク $\pm 25 \mathrm{~mm}$ ) を用いた。 最大引張荷重 $18000 \mathrm{~N}$, 最小荷重 $0 \mathrm{~N}$, 周波 数 $3 \mathrm{~Hz}$ の荷重制御三角波の負荷条件にて, 切欠きの両 
側から長さ約 $0.5 \mathrm{~mm}$ の予き裂を導入した. その後, 予 き裂の延長線上にレーザ照射領域の中心がほぼ一致す るようにパルスレーザを照射した。出力 $675 \mathrm{~W}$ ，照射時 間 $0.02 \mathrm{~s}$ ，周波数 $10 \mathrm{~Hz}$ のレーザ照射条件下で，同一位 置に 5 回照射した。以降，本試験片を”レーザ照射材”と 表記する．なお，本レーザ照射条件は，レーザ照射半径 が切欠きの先端の半径とおおよそ一致する $r_{0}=0.7 \mathrm{~mm}$ となるように試行錯誤して決定した.また，比較材とし てパルスレーザを照射していない”未照射材”も準備し た. 未照射材およびレーザ照射材の切欠き部片側近傍の 外観写真とパルスレーザの照射位置の模式図を Fig. 9(a) に示す. Pattern 1 では, き裂先端とレーザの中心が $2 \mathrm{~mm}$, Pattern 2 では，き裂先端とレーザの中心が $3 \mathrm{~mm}$ となる ようにレーザを照射した。

その後, 最大引張荷重 $9800 \mathrm{~N}$, 最小荷重 $0 \mathrm{~N}$, 周波数 $3 \mathrm{~Hz}$ の荷重制御三角波の条件下で疲労試験を行った．本 疲労試験条件は, 無限遠における応力と降伏応力の比が 0.3 となるよう最大引張荷重を設定した ${ }^{13)}$.

疲労試験中, デジタル一眼レフカメラ（EOS60D, キャ ノン(株)）により切欠き部周辺を撮影することで繰返し 負荷に伴うき裂長さの変化を評価した。 その際, 解像度 を $39586 \mathrm{dot} / \mathrm{mm}^{2}$, シャッター速度を $1 / 1000 \mathrm{~s}$ とし, サン プリング間隔 $167 \mathrm{~s}$ で自動撮影した。撮影した画像から, デジタル画像計測ソフトマイクロアナライザ（Micro analyzer ver.1.1，日本ポラデジタル（株）製）を用いてき 裂長さを測定した. その際, 切欠きの両側から進展する き裂の $x$ 軸に対する投影長さをき裂長さ $2 a$ として測定し た。

疲労試験において, 任意の繰返し数に対するき裂進展 速度 $d a / d N$ を以下のように算出した。レーザ照射後に行 った疲労試験での繰返し数 $N$ を横軸に, き裂長さ $a$ を縦軸 にプロットする。そして，このプロット点に対して最小 二乗法により 6 次関数で近似する。これにより得られた 繰返し数を変数にもつ関数 $a(N)$ を $N$ で 1 階微分すること でき裂進展速度 $d a / d N$ を算出した。

\section{$3 \cdot 4$ 試験結果}

疲労試験後の未照射材およびレーザ照射材の切欠き 部片側近傍の外観写真とき裂進展経路をトレースした ものを Fig. 9(b)に示す. 疲労試験により切欠きから発生 していた予き裂はほぼ水平に進展し，レーザ照射材では き裂先端がレーザ照射領域に到達し，停留した。

Fig. 11 にき裂長さと疲労き裂進展速度 $d a / d N$ の関係を 示す. 図中の○印は未照射試験片により得られた結果,

○印は Pattern 1， $\boldsymbol{\Delta}$ 印は Pattern 2 による結果を示す。は じめに Pattern 1 の結果に注目すると, 疲労き裂先端がパ ルスレーザ照射位置に近づくにつれてき裂進展速度が 顕著に低下していることがわかる，この傾向は，先に示 した有限要素解析により予測された結果と一致してい る．つぎに Pattern 2 の結果においては，パルスレーザ照 射位置に達するまでは疲労き裂進展速度は未照射材の
それとほぼ一致している。しかし, Pattern 2 と同様にき 裂先端がパルスレーザ照射領域に近づくにつれて急速 に減速している。

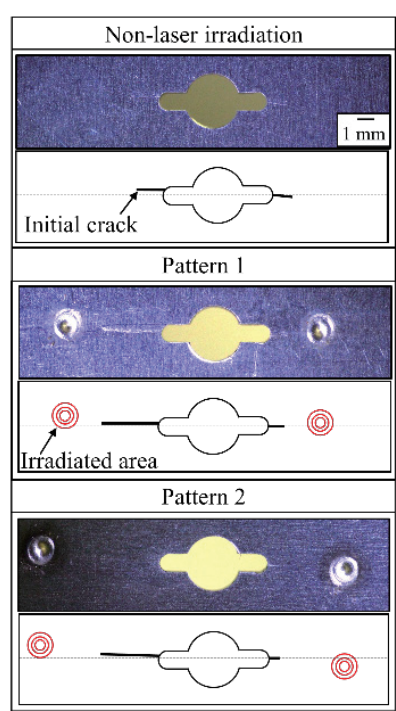

(a) Before fatigue test

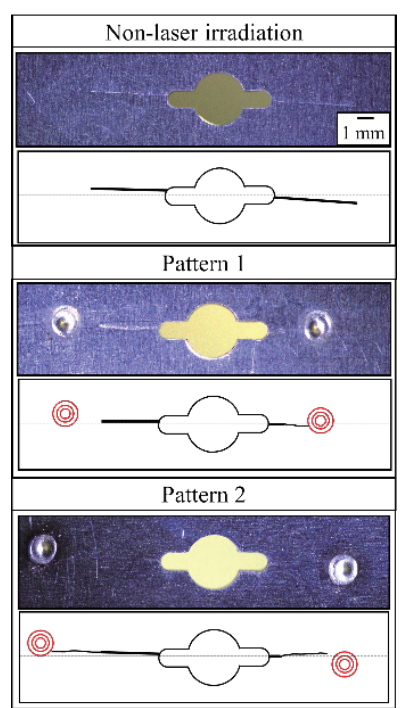

(b) After fatigue test
Fig. 9 The photo around the notch and pulsed laser irradiation position.

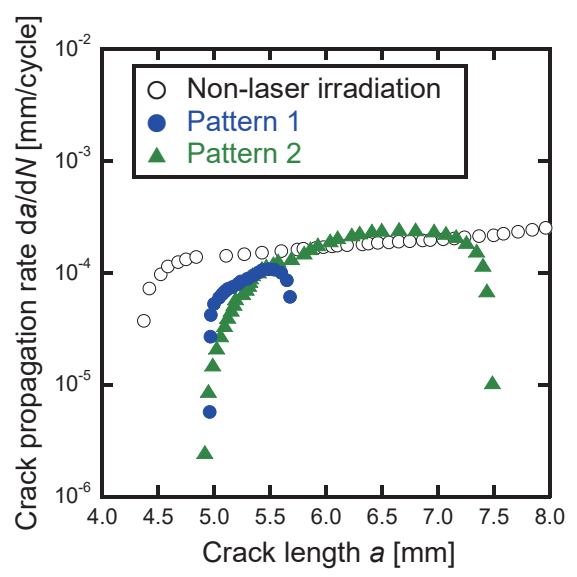

Fig. 10 Relationship between crack length $a$ and crack propagation rate $d a / d N$.

\section{3・5 Hole Drilling 法による残留応力測定}

ここではレーザ照射材におけるレーザ照射周りの残 留応力を Hole Drilling 法 (HD 法) 14)に基づき実測するこ とを試みた. Fig. 11 に HD 法による残留応力計測方法を 説明するための模式図を示す.

HD 法による残留応力計測方法は以下の通りである. 円形状のレーザ照射領域の中心から距離 $r_{1}$ に半径方向な らびに周方向にふたつのひずみゲージを貼り付ける。そ の後, ひずみゲージをブリッジボックスに接続し，その 電圧出力を動ひずみ計にて増幅する．動ひずみ計のバラ ンスをとった後, 直径 $2 r_{0}$ のドリルでレーザ照射領域を 孔加工する．機械加工後, 半径方向のひずみゲージの出 力 $e_{r r}$ ならびに周方向の出力 $e_{\theta \theta}$ を計測する. これらのひ ずみ值を平面応力状態における一般化されたフックの 法則に代入して応力成分を求める. すると, 


$$
\sigma_{r r}=\frac{E}{1+v}\left[e_{r r}+\frac{v}{1-v}\left(e_{r r}+e_{\theta \theta}\right)\right]
$$

となる.ここで, $v$ は対象材料のポアソン比である.よっ て, 式(5)の負の值と $r=r_{1}$ を式(2)に代入して得られる応 力值が等しいことから，

$$
-\frac{E}{2}\left(\frac{\varepsilon r_{0}}{r_{1}^{2}}\right)=-\frac{E}{1+v}\left[e_{r r}+\frac{v}{1-v}\left(e_{r r}+e_{\theta \theta}\right)\right]
$$

これによりパラメータとは,

$$
\varepsilon=\frac{2}{1-v^{2}}\left(\frac{r_{1}^{2}}{r_{0}}\right)\left[e_{r r}+v e_{\theta \theta}\right]
$$

これを式(1)に代入して残留応力 $\sigma_{R}$ は,

$$
\sigma_{R}=-\frac{E}{1-v^{2}}\left(\frac{r_{1}}{r_{0}}\right)^{2}\left[e_{r r}+v e_{\theta \theta}\right]
$$

となり，ひずみゲージにて計測された $e_{r r}$ と $e_{\theta \theta}$ を式(8)に 代入することで残留応力を評価できる，なお，本手法の 妥当性は別途行った有限要素解析により確認している.

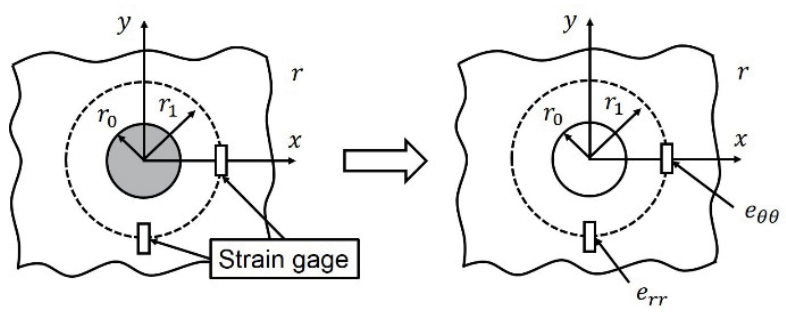

Fig. 11 Schematic illustration of measurement procedure of residual stress based upon a hole drilling technique.

Fig. 12 に $r_{1}=2.7 \mathrm{~mm}$ としてひずタゲージを貼り付け た SUS304H 円板の外観写真を示す.この結果, HD 法に より得られたレーザ照射領域内での残留応力值は 722 $\mathrm{MPa}$ であり, 引張残留応力であることがわかった．よっ て本測定結果は, 疲労き裂先端近傍をレーザ照射するこ とで疲労き裂進展が遅延したことを裏付けているもの といえる.

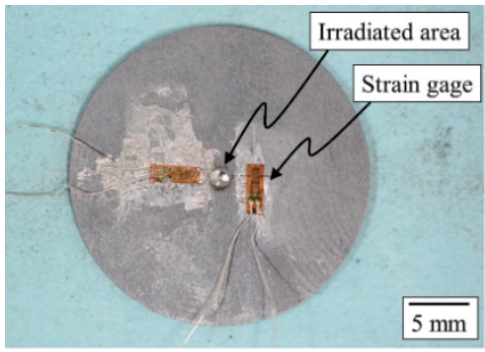

Fig. 12 Appearance of test piece with strain gage.

\section{3 ・6 有限要素解析による疲労試験結果の検証と考察}

つぎに HD 法で計測された残留応力に基づいて有限要 素解析による疲労き裂進展解析を行った．解析モデルは 2 ・2 節と同一である。ただし，初期き裂長さ，レーザ照 射位置およびレーザ照射領域の半径は Pattern 1，Pattern 2 と等しくなるようにした。 また, レーザ照射領域を模 擬した弾性円板内には，HD 法によって得られた残留応 力 $\sigma_{R}$ と等しくなる初期応力 $\sigma^{i n i}$ を付与した。 また，疲労 き裂進展に必要なパリス則の材料定数については, Fig.
10 における未照射材の結果に基づいて $C=1.77 \times 10^{-14}, m$ $=2.27$ とした. Table 5 に本解析で設定したパラメータを まとめて示す.

Fig. 13 に疲労試験結果と解析結果を比較したものを 示寸，図中の $\bigcirc \triangle$ 印は試験結果，実線と破線は解析結果 である。図より，き裂長さに対する疲労き裂進展速度の 変化には違いが認められるものの, 疲労き裂の停留長さ は両者で概ね一致しているといえる。具体的には, Pattern1 では実験值との相対誤差が 2.78\%, Pattern2 では $7.79 \%$ であった. 以上により，ここに計測された残留応力 值は適切な結果と考えられた。

Table 5 Parameters for analysis.

\begin{tabular}{|c|c|c|}
\hline & Pattern 1 & Pattern 2 \\
\hline$r_{0}[\mathrm{~mm}]$ & \multicolumn{2}{|c|}{0.7} \\
\hline$r[\mathrm{~mm}]$ & 2 & 3 \\
\hline Initial crack length $[\mathrm{mm}]$ & \multicolumn{2}{|c|}{4.9} \\
\hline$\varepsilon[\mathrm{mm}]$ & \multicolumn{2}{|c|}{-0.005} \\
\hline Initial stress $\sigma^{\text {ini }}[\mathrm{MPa}]$ & \multicolumn{2}{|c|}{2059} \\
\hline
\end{tabular}

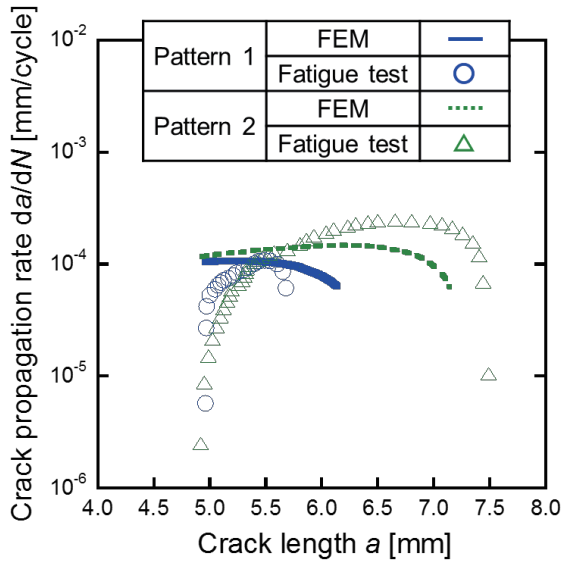

Fig. 13 Relationship between crack length $a$ and crack propagation rate $d a / d N$.

\section{4 結言}

本研究では，薄肉構造部材に生じた疲労き裂に対し， パルスファイバーレーザをスポット照射することでき 裂進展を抑制させる新しい補修方法を提案し，有限要素 解析ならびに疲労試験によりその有効性を検討した。得 られた知見を以下にまとめる。

・ パルスレーザによりスポット照射領域に生じる残留 応力を, 円孔に弾性円板を圧入するモデルにより評 価した.このモデルに基づき, 疲労き裂進展の有限要 素解析を行った。 その結果, き裂の延長線上に弾性円 板を配置し，かつ弾性円板に引張残留応力が生じる ような状況下では，き裂の開口方向に対して圧縮の 残留応力が付与されるため, き裂進展速度が低下寸 ることがわかった. また, 弾性円板をき裂先端のでき るだけ近い位置に配置するほどき裂進展抑制効果が 高いことがわかった。 
・厚さ $1 \mathrm{~mm}$ の SUS304H 平板材を対象に疲労試験を行 い，パルスレーザ照射が疲労き裂進展速度に及ぼす 影響を検討した.この結果, き裂進展方向の延長線上 かつき裂先端近傍にパルスレーザを照射することで, 疲労き裂進展を著しく抑制できることが示された。

また, Hole Drilling 法によりレーザ照射領域に 722 $\mathrm{MPa}$ の引張残留応力が生じていた.

\section{参考 文 献}

1) D. H. R. Jones, “Creep failures of overheated boiler, superheater and reformer tubes", Engineering Failure Analysis, Vol. 11, pp. 873893 (2004)

2) M. R. Bache, R. E. Johnston, T. S. Cook, B. J. Robinson and J. F. Matlik, "Crack growth in the creep-fatigue regime under constrained loading of thin combustor alloy", International Journal of Fatigue, Vol. 42, pp. 82-87 (2012).

3) T. Marazani, D. M. Madyira and E. T. Akinlabi, "Repair of cracks in metals: a review", Procedia MANUFACTURING, Vol. 8, pp.673679 (2017)

4) K. Hasagawa, Y. Li and M. Shimomoto, "Plastic collapse moment for weld overlay pipe with multiple circumferential flaws", Journal of Pressure Vessel Technology, Vol. 135, pp. 051208-1-8 (2013)

5) K. J. Pallos, “Gas turbine repair technology”, GE Power Systems, GER-3957B, pp. 1-2.

6) W. C. Wang, B. Zhou, S. H. Yang and Q. Y. Zhang, "Recent advances in soft optical grass fiber and fiber lases", Progress in Materials Science, Vol. 101, pp.90-171 (2019).
7) M. Arai, K. Ito, T. Morinaga, T. Suidzu, H. Yokota, H. Nishida and K. Toshitani, "Development of pulse-laser repairing technique for fatigue crack”, Boiler Research, Vol. 412, pp. 11-15 (2018).

8) M. Arai, K. Inada, T. Morinaga, K. Ito, H. Yokota and T. Suidzu, "Delaying effect of fatigue crack propagation by single-pulse laser irradiation", Proceedings of $18^{\text {th }}$ International Conference on Experimental Mechanics, (July, 2018), Belgium.

9) M. Arai, “Application of distributed dislocation method to curved crack moving near a press-fitted inclusion in a two-dimensional infinite plate", Engineering Fracture Mechanics, Vol. 218 (2019), doi.org/10.1016/j.engfracmech.2019.106609.

10) S. E. Moussavi Torshizi and M. Ebrahimi, "Failure analysis of gas turbine transition pieces, leading to a solution for prevention", Engineering Failure Analysis, Vol. 32, pp.402-411 (2013).

11) T. Mukherjee, W. Zhang and T. Deboy, “An improved prediction of residual stresses and distortion in additive manufacturing", Computational Materials Science, Vol. 126, pp. 360-372 (2017).

12) M. Kimura, K Yamaguchi, S Matsuoka and E Takeuchi, "Fatigue fracture mechanism maps for SUS304 stainless steel", High Pressure Institute of Japan, Vol. 41, No. 5, pp. 216-223 (2005).

13) K Ogura, "Small yield conditions", The Society of Material Science of Japan, Vol. 32, No. 361, pp. 1194-1199 (1983).

14) J. Mathar, "Determination of initial stresses by measuring the deformations around drilled holes", Trans. ASME. E., 56, pp. 249253 (1934). 